\title{
STANDAR DAN UKURAN KINERJA DALAM MENILAI KINERJA SUATU ORGANISASI \\ (Studi Kasus Koperasi Jasa Keuangan Syariah Baitul Mall Wat Tamwil Sejahtera Belimbing Kajian Dalam Teori Manajemen Dakwah)
}

\author{
Yummil Hasan \\ Fakultas Dakwah dan Ilmu Komunikasi UIN Imam Bonjol Padang \\ (E-mail: yummilhasan@gmail.com) \\ Nur Dewana \\ Fakultas Dakwah dan Ilmu Komunikasi UIN Imam Bonjol Padang \\ (E-mail: nurdewana@gmail.com)
}

\begin{abstract}
Performance appraisal is the periodic determination of the operational effectiveness of an organization, part of the organization, and its personnel, based on predetermined strategic goals, standards and criteria. With performance appraisal, we can predict that in the future this company will continue to run or not compete with organizations that have more competitive employees, because competitive employees can be faster to realize the goals and objectives desired by the company, if employees cannot developing or not implementing the program and targets charged by the organization well then the same as the organization itself will be the same from year to year there is no change because the employees owned cannot realize the goals and objectives desired by the organization or company.

Keyword: Performance Standards, Performance Measures, Performance Appraisals, Credit, BMT

Abstrak

Penilaian kinerja adalah penentuan secara periodik efektivitas operasional suatu organisasi, bagian organisasi, dan personelnya, berdasarkan sasaran strategik, standar, dan kriteria yang telah ditetapkan sebelumnya. Dengan penilaian kinerja itulah kita bisa memprediksikan kedepannya perusahaan ini akan tetap berjalan atau kalah bersaing dengan organisasi-organisasi yang memiliki karyawan yang lebih kompetitif, karena karyawan yang kompetitif bisa lebih cepat untuk merealisasikan tujuan dan sasaran yang diinginkan oleh perusahaan, jika karyawan yang dimiliki tidak bisa berkembang atau tidak melaksanakan program dan sasaran yang dibebankan organisasi dengan baik maka sama pula dengan organisasinya itu sendiri akan sama dari tahun ke tahun tidak ada perubahan karena karyawan yang dimiliki tidak bisa merealisasikan tujuan dan sasaran yang diinginkan oleh organisasi atau perusahaan.

Kata kunci: Standar Kinerja, Ukuran Kinerja, Penilaian Kinerja, KJKS, BMT
\end{abstract}




\section{A. Pendahuluan}

Di dalam lembaga yang berbentuk organisasi atau perusahaan pasti ada yang namanya sumber daya manusia atau yang banyak dikenal dengan istilah Sumber Daya Manusia. Sumber daya manusia berperan penting bagi kelangsungan sebuah organisasi, pengertian sumber daya manusia adalah orang yang berbakat dan bersemangat tinggi yang tersedia bagi organisasi sebagai konstributor potensial untuk menciptakan dan merealisasikan tujuan, misi, serta organisasi. ${ }^{1}$

Di sebuah organisasi itu juga pasti tidak akan terlepas dari sumber daya manusia walaupun ada juga sumberdaya-sumberdaya yang lain seperti sumber daya finalsial itu juga penting akan tetapi disini pokok pembahasan terkait dengan sumberdaya manusianya. Pada organisasi sumber daya manusia adalah pelaku utama yang merealisasikan target di sebuah organisasi yang biasa disebut karyawan. Karyawan adalah seorang yang bekerja untuk organisasi dan menjalankan tujuan yang telah ditetapkan oleh sebuah organisasi.

Salah satu indikator yang dapat digunakan untuk stabilitas organisasi adalah kinerja. ${ }^{2}$ Kinerja adalah keberhasilan personil, tim, atau unit organisasi dalam mewujudkan sasaran strategik yang telah ditetapkan sebelumnya dengan perilaku yang diharapkan. Keberhasilan pencapaian sasaran strategik yang menjadi basis pengukuran kinerja perlu diukur.

Kinerja organisasi atau perusahaan adalah sebagai hasil- hasil fungsi pekerjaan atau kegiatan seseorang atau kelompok dalam suatu organisasi yang dipengaruhi oleh berbagai faktor untuk mencapai tujuan organisasi dalam priode waktu tertentu.

Faktor yang berpengaruh terhadap hasil pekerjaan atau prestasi kerja seseorang atau kelompok terdiri dari dua faktor interm dan ekstren. Faktor intrem yang mempengaruhi kinerja karyawan atau kelompok terdiri dari kecerdasan, keterampilan, kestabilan emosi, motivasi, persepsi peran, kondisi keluarga,

\footnotetext{
1 Al, Siti, Fajar dan Tri Heru, Manajemen Sumberdaya Manusia, (Yogyakarta:sekolah tinggi ilmu manajemen YKPN, 2010), h. 2.

2 Bayu Prawira, Ringkasan Tesis: Pengaruh Motivasi Terhadap Kinerja LPP (Lembaga Pembina Posyandu) di Kecamatan....,http://www.tesis-ilmiah.co.oc diakses pada 20-10-2013), h. 5.
} 
kondisi fisik seseorang dan karakteristik kelompok kerja. Sedangkan pengaruh faktor eksternal antara lain berupa peraturan, ketenagan kerjaan, keinginan pelanggan, pesaing, nilai-nilai sosial, serikat buruh, kondisi ekonomi, perubahan lokasi kerja, dan kondisi pasar. Pelaksanaan hasil pekerjaan atau prestasi kerja tersebut diarahkan untuk mencapai tujuan organisasi dalam jangka waktu tertentu. Dengan demikian kinerja perusahaan adalah fungsi hasil-hasil pekerjaan atau kegiatan yang ada dalam perusahaan yang dipengaruhi faktor intern dan ekstern organisasi dalam mencapai tujuan yang ditetapkan selama priode waktu tertentu.

Karyawan juga bisa belajar dan mengetahui seberapa besar kontribusi mereka terhadap organisasi dan seberapa produktifnya karyawan yang bekerja di dalam organisasi tersebut. Sebagaiman didalam Al-Quran menjelaskan soroh atTaubah ayat 105:

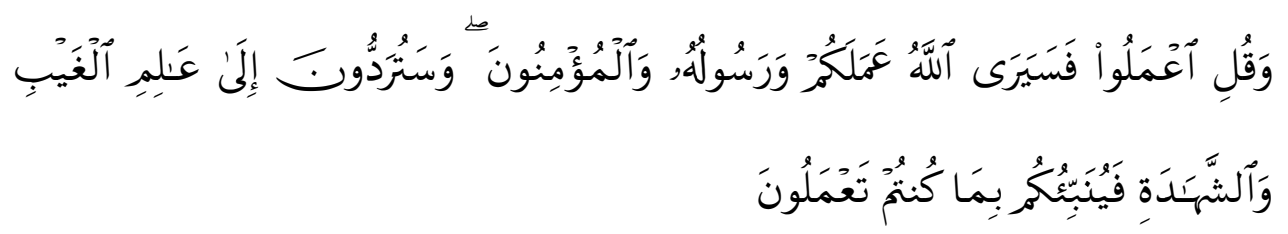

Dan Katakanlah: "Bekerjalah kamu, Maka Allah dan Rasul-Nya serta orang-orang mukmin akan melihat pekerjaanmu itu, dan kamu akan dikembalikan kepada (Allah) yang mengetahui akan yang ghaib dan yang nyata, lalu diberitakan-Nya kepada kamu apa yang telah kamu kerjakan.

Ayat di atas menjelaskan bahwa Allah menyuruh ummatnya untuk bekerja dan berbuat baik karna Allah maha melihat dan maha mendegar apa yang di kerjakan manusia di muka bumi ini, pada hari kiamat nanti Allah akan memperlihatkan kelakuan ummatnya sewaktu di dunia.

Karyawan pun bisa juga menjadi tolok ukur keberhasilan sebuah organisasi. Jika sebuah organisasi atau perusahaan memiliki karyawan yang kompetitif dan bisa melaksanakan juga untuk mencapai program yang telah direncanakan oleh organisasi tersebut maka keberhasilan atau kesuksesan pun akan cepat terrealisasikan.

Dengan demikian dapat dikatakan bahwa Penilaian kinerja adalah penentuan secara periodik efektivitas operasional suatu organisasi, bagian organisasi, dan personelnya, berdasarkan sasaran strategik, standar, dan kriteria yang telah ditetapkan sebelumnya. Dengan penilaian kinerja itulah kita bisa 
memprediksikan kedepannya perusahaan ini akan tetap berjalan atau kalah bersaing dengan organisasi-organisasi yang memiliki karyawan yang lebih kompetitif, karena karyawan yang kompetitif bisa lebih cepat untuk merealisasikan tujuan dan sasaran yang diinginkan oleh perusahaan, jika karyawan yang dimiliki tidak bisa berkembang atau tidak melaksanakan program dan sasaran yang dibebankan organisasi dengan baik maka sama pula dengan organisasinya itu sendiri akan sama dari tahun ke tahun tidak ada perubahan karena karyawan yang dimiliki tidak bisa merealisasikan tujuan dan sasaran yang diinginkan oleh organisasi atau perusahaan.

Jika program dan sasaran yang di inginkan dapat terlaksanakan maka yang akan diperoleh hasilnya yaitu sebuah keberhasilan. Adapun salah satu tolok ukur dari keberhasilan adalah bertambahnya jumlah pendapatan dan nasabah yang mempercayaai dananya di KJKS BMT Sejahtera. Baitul Mal Wa Tamwil (BMT) terdiri dari dua istilah, yaitu baitul mal dan baitut tamwil. Baitul maal lebih mengarah pada usaha-usaha pengumpulan dan penyaluran dana yang non profit, seperti zakat, infak dan shodaqoh.

Dengan semakin bermunculannya BMT di seluruh Indonesia maka semakin dikenalnya ekomomi syariah di masyarakat Indonesia oleh sebab itulah semakin menambah pula SDM yang dibutuhkan untuk perusahaan tersebut, kinerja yang baik sangat dibutuhkan disetiap lembaga, akan tetapi didalam sebuah perusahaan pastilah ada yang namanya permasalahan tetapi disini sumberdaya manusianya faktor utama yang merealisasikan tujuan dan sasaran yang ada didalam perusahaan. Koperasi Jasa Keuangan Syariah (KJKS) Baitul maal Wat Tamwil (BMT) didirikan tanggal 13 Oktober 2005. Saat ini KJKS BMT Sejahtera telah bergabung dalam perhimpun BMT Indonesia (PBMTI) yang berkantor di Equiy Tower lantai 27 SCBDD Compelek J1. Sudirman Kapling 5253 Jakarta. Visi KJKS BMT Sejahtera menjadi simpan pinjam syari'ah yang sehat, kuat dan amanah yang dikelola sumber daya insani yang bertaqwa dalam melayani anggota melalui peningkatan hubungan silaturhami menuju terbentuknya komoditas sosial yang Ridhoi Allah. Misi KJKS BMT Sejahtera melaksanakan tata kelola BMT berdasarkan standar kesehatan KSP syari'ah, 
melaksanakan service excelen dan akuisisi dan retensi custumer secara terus menerus. $^{3}$

Saat observasi yang penulis lakukan pada Koperasi Jasa Keuangan (KJKS) Baitul Maal wat Tamwil (BMT) bahwa kinerja di KJKS BMT Sejahtera tidak sesuai pendapatan dengan standar kinerja atau target yang di rencanakan pertahun dilihat urain standar kinerja atau target sebagai berikut pada tahun 2010 Rp.125.000.000, pada tahun $2011 \mathrm{Rp}$ 365.904.360, pada tahun $2012 \mathrm{Rp}$. 316.800.000,pada tahun 2013 Rp.531.000.000, pada tahun 2014 Rp. 700.000.000, Sementara KJKS BMT Sejahtera berhasil mendapatkan keuntungan hanya 2 tahun yaitu tahun 2011 dan 2013.

\section{B. Landasan Teoritis}

\section{Pengertian Manajemen Sumber Daya Manusia}

Manajemen adalah ilmu dan seni mengatur proses pemanfaatan sumber daya manusia dan sumber-sumber daya lainnya secara efektif dan efisien untuk mencapai suatu tujuan tertentu. Manajemen ini terdiri dari enam unsur (6 M) yaitu: man, money, methode, materials, machines, dan market. ${ }^{4}$ Manajemen sumber daya manusia (SDM) merupakan salah satu bidang dari manajemen umum yang meliputi segi-segi perencanaan, pengorganisasian, pelaksanaan dan penggendalian. Proses ini terdapat dalam fungsi atau bidang produksi, pemasaran, keuangan, maupun kepengawaian. Karena sumber daya manusia (SDM) dianggap semakin penting perannya dalam pencapaian tujuan perusahaan. ${ }^{5}$

\section{Tujuan manajemen sumber daya manusia}

Tujuan Manajemen Sumber daya manusia secara tepat sangatlah sulit untuk dirumuskan karena sifatnya bervariasi dan tergantung pada penahapan perkembangan yang terjadi pada masing-masing organisasi.

Menurut Cushway dalam Irianto (2001) tujuan manajemen sumber daya manusia meliputi:

a. Memberi pertimbangan manajemen dalam membuat kebijakan sumber daya manusia untuk memastikan bahwa organisasi memiliki pekerja yang

\footnotetext{
${ }^{3}$ Rika Muldan, Wawancara: 03 Februari 2015

${ }^{4}$ Malayu Hasibuan, Manajemen Sumber Daya Manusia, (Jakarta PT Bumi Aksara, 2010$)$, h. 6.

${ }_{5}$ Veithzal Rivai, Manajemen Sumber Daya Manusia, (Jakarta PT Granfindo persada, 2006), h.1.
} 
bermotivasi dan berkinerja yang tinggi, memiliki pekerjaan yang lalu siap mengatasi perubahan dan memenuhi kewajiban pekejaan ssecara legal.

b. Mengimplementasikan dan menjaga semua kebijakan dan prosedur sumber daya manusia yang memungkinkan organisasi mampu mencapai tujuanya.

c. Membantu dalam mengembangkan arah keseluruhan organisasi dan strategi, khususnya yang berkaitan dengan implikasi sumber daya manusia.

d. Memberi dukungan dan kondisi yang akan membantu manajer mencapai tujuan.

e. Menangani berbagai krisis dan situasi sulit dalam hubungan antara pekerja untuk menyakinkan bahwa mereka tidak menghambat organisasi dalam mencapai tujuan.

f. Menyediakan media komunikasi antara pekerja dan manajemen organisasi.

g. Bertindak sebagai pemelihara standar organisasional dan nilai dalam manajemen sumber daya manusia.

\section{Fungsi manajemen sumber daya manusia}

Sudah merupakan tugas manajemen sumber daya manusia untuk mengelola manusia seefektif mungkin agar diperoleh suatu satuan SDM yang merasa puas dan memuaskan. Manajemen sumber daya manusia merupakan bagian dari manajemen umum yang memfokuskan dari SDM. Adapun fungsifungsi manajemen SDM seperti halnya fungsi manajemen umum yaitu:

a. Fungsi manajerial

1) Perencanaan (planning)

2) P enggorganisasian (organizing)

3) Pengarahan (directing)

4) Pengendalian (controling)

b. Fungsi operasional

1) Penggadaang tenaga kerja (SDM)

2) Pengembangan

3) Kompensasi

4) Pengintegrasian

5) Pemiliharaan

6) Pemutusan hubungan kerjas. ${ }^{6}$

Jadi dapat penulis pahami Perusahaan atau organisasi dalam bidang sumber daya manusia tentunya menginginkan agar setiap saat memiliki sumber daya manusia yang berkualitas dalam arti memenuhi persyaratan kompetensi untuk didayagunakan dalam usaha merealisasikan visi dan mencapai tujuan-tujuan jangka pendek dan jangka panjang, sumber daya seperti itu hanya diperoleh dari karyawan atau anggota organisasi atau perusahaan.

\footnotetext{
${ }^{6}$ Veithzal Rivai, Manajemen Sumber..., h. 14-15.
} 


\section{Indikator Kinerja Organisasi}

a. Pengertian Standar Kinerja

Standar kinerja adalah tolok ukur minimal kinerja yang harus dicapai karyawan secara individual atau kelompok pada semua indikator kinerjanya atau dapat diartikan standar kinerja merupakan eksperesi mengenai ambang kinerja. Persyaratan, atau harapan yang harus dicapai untuk setiap elemen pada level kinerja tertntu. ${ }^{7}$

Timpe (1988) menyatakan bahwa standar kinerja dapat di buat untuk setiap individu dengan berpedoman pada uraian jabatan. Proses penulisan standar kinerja dimulai ketika pengawas dan pengawai mendiskusikan pekerjaan.langkah pertama meliputi penulisan semua tugas dan tanggung jawab karyawan. Pengawai juga mempertimbangkan pemahamannya tentang harapan-harapan utama mungkin dimiliki pengawas. Setelah menyelesaikan proses penulisan penyuntingan, dan integrasi, standar kinerja yang disepakati untuk dituliskan dapat dikuatifikasikan atau di ukur di capai. Sejalan dengan pendapat timpe diatas simamora menyatakan (2004) bahwa faktor kritis yang berhubungan dengan keberhasilan jangka panjang organisasi adalah kemampuanya untuk mengukur seberapa baik pengawai- pengawainya berkarya dan menggunakan infomusi untuk memastikan bahwa pelaksanaan memenuhi standar saat ini dan meningkat sepanjang waktu. ${ }^{8}$

Adapun fungsi utama dari standar kinerja adalah sebagai tolok ukur (bechmark) untuk menentukan keberhasilan dan tidak keberhasilan kinerja ternilai dalam melaksanakan pekerjaannya. Standar kinerja merupakan target, atau tujuan upaya kerja karyawan dalam kurun waktu tertentu, dalam melaksanakan pekerjaan karyawan harus mengarahkan semua tenaga, pikiran, keterampilan, pengetahuan, dan waktu kerjanya untuk mencapai apa yang ditentukan standar kinerjanya. ${ }^{9}$ (Wirawan, 2009 : 66).

Standar kinerja pekerjaan (performance standard) menetapkan tingkat kinerja pekerjaan yang diharapkan dari pelaksana pekerjaan dan kriteria

\footnotetext{
${ }^{7}$ Wirawan, Evaluasi Kinerja Sumber Daya Manusia, (Jakarta, 2009), h. 65.

${ }^{8}$ Husaini Usman, Manajemen, (Jakarta: PT Bumi Aksara, 2010), h. 449.

${ }^{9}$ Wirawan, Evaluasi Kinerja Sumber..., h. 66
} 
pengukuran kesuksesan pekerjaan. Standar kinerja pekerjaan membuat eksplisit kuantitas dan atau kualitas kinerja yang diharapkan dalam tugas dasar yang ditentukan sebelumnya dalam deskripsi pekerjaan. Standar kinerja pekerjaan ini biasanya berupa pernyataan mengenai kinerja yang dianggap diterima dan dapat dicapai atas sebuah pekerjaan tertentu. Adapun beberapa persyaratan yang harus dipenuhi dalam standar kinerja pekerjaan diantaranya adalah:

1) Standar kinerja harus relevan dengan individu dan organisasi.

2) Standar kinerja harus stabil dan handal.

3) Standar kinerja harus membedakan antara pelaksanaan pekerjaan yang baik, sedang dan buruk.

4) Standar kinerja harus dijabarkan dalam angka.

5) Standar kinerja harus mudah diukur.

6) Standar kinerja harus dipahami oleh karyawan dan penyelia.

7) Standar kinerja harus memberikan interprestasi yang tidak bias. ${ }^{10}$

b. Pengertian Ukuran Kinerja

Ukuran kinerja adalah pada akhir kurun waktu (periode) yang ditetapkan. Tibalah saatnya untuk melakukakan penilaian. Yaitu membandingkan antara hasil yang sebenarnya diperoleh dengan yang direncanakan. Dengan kata lain sasaransasaran tersebut harus diteliti satu persatu mana yang telah dicapai sepenuhnya (100\%), mana yang di atas standar (target) dan mana yang di bawah target atau tidak tercapai penuh. ${ }^{11}$ ( Achmad, $2002: 159$ ).

Ukuran kinerja organisasi salah satunya melalui metode balanced score card yang dipelopori oleh Robert S. Kaplan dan David P. Norton. Balanced score card adalah suatu sistem manajemen, pengukuran dan pengendalian yang dapat memberikan pemahaman pada manajer tentang performa bisnis dalam perspektif keuangan, customer, proses bisnis internal dan pembelajaran dan pertumbuhan perusahaan. $^{12}$

Menurut Mulyadi pengukuran kinerja dapat dimanfaatkan oleh manajemen untuk

10 file:///C:/Users/user/Documents/standar-dan-prosedur-kinerja-pekerjaan.html (di akses 14 Mei 2015 pukul 09:00 wib).

11 Achmad, S. Ruky. Sistem Manajemen Kinerja, (Jakarata: PT Gramedia Pustaka, 2002), h. 159.

${ }_{12}$ Sony Yuwono, dkk, Petunjuk Praktis Penyusunan Balance Scorecard Menuju Organisasi yang Berorientasi pada Strategi, (Jakarta: Gramedia Pustaka Utama, 2003), h. 9 . 
1) Mengelola operasi organisasi secara efektif dan efesien melalui pemotivasian karyawan secara maksimum.

2) Membentuk pengambilan keputusan yang bersangkutan dengan karyawan seperti promosi, pemberhentian dan mutasi.

3) Mengidentifikasi kebutuhan pelatihan dan pengembangan karyawan dan untuk menjadikan kreteria seleksi dan evaluasi program pelatihan karyawan.

Secara formal, produk akhir dan hasil pengukuran kinerja diwujudkan dalam suatu laporan yang disebut laporan kinerja sebagai suatu alat laporan yang berisikan informasi- informasi penting tentang tercapainya atau tidaknya kinerja yang telah ditetapkan. ${ }^{13}$

Penggunaan balanced score card sebagai pengukur kinerja organisasi sudah banyak diterapkan di perusahaan-perusahaan. Secara tradisional kinerja perusahaan diukur dari aspek finansial. Untuk jangka waktu yang lama, model pengukuran ini tidak dapat diterima. Karena finansial adalah indikator yang tertinggal, yang lebih penting kebanyakan asset perusahaan adalah didapat dari nilai asset yang tidak berwujud, asset yang tidak berwujud antara lain karyawan, inovasi dan hubungan pelanggan yang semua itu tidak tertuis di neraca keuangan. $^{14}$

Jadi dapat penulis jelaskan ukuran kinerja organisasi itu kengiatan awal dari proses penilain, untuk memberi angka pada objek atau kejadian menurut aturan-aturan tertentu yang menyebabkan angka itu mempunyai arti bagi perusahaan.

\section{Penilaian Kinerja}

Penilaian kinerja salah satu cara yang dapat digunakan untuk melihat perkembangan perusahaan adalah dengan cara melihat hasil penilaian kinerja, sasaran yang menjadi objek penilaian kinerja yaitu kecakapan, kemampuan karyawan dalam melaksanakan suatu pekerjaan atau tugas yang dievaluasi dengan menggunakan tolok ukur tertentu secara objektif dan dilakukan secara berkala. Dari hasil penilaian dapat dilihat kinerja perushaan yang dicerminkan oleh kinerja

${ }^{13}$ Cecilia, Srimindarti, Balanced Scorecard Sebagai Alternatif Untuk Mengukur Kinerja, 2006, http://www.duniaesai.com, 15 Oktober 2008

${ }_{14}$ (Http:// metronews/videoprogram/detail/2013/02/23/163/9 /3850/ robert- skaplan/ face-with- desi - anwar). 
karyawan atau dengan kata lain, kinerja merupakan hasil kerja konkret yang dapat diamati dan dapat diukur. Peenilain kinerja mengacu pada suatu sistem formal dan tersturuktur yang digunakan untuk mengukur, menilai dan mempengaruhi sifatsifat ynag berkaitan dengan pekerjaan, perilaku dan hasil, termasuk tingkat ketidak hadiran. Dengan demikian, penilian prestasi adalah merupakan hasil kerja karyawan dalam lingkup tanggung jawabnya. ${ }^{15}$

\section{Koperasi Jasa Keuagan Syari'ah (KJKS) Baitul Maal Wat Tamwil (BMT)}

Koperasi jasa keuangan syariah (KJKS) adalah koperasi yang kegiatan usahanya bergerak di bidang pembiayaan, investasi, dan simpanan dengan pola bagi hasil (syariah) sebagai bagian dari kegiatan usaha koperasi yang bersangkutan. ${ }^{16}$

BMT merupakan salah satu bentuk dari lembaga keuangan mikro bukan bank yang beroperasi berdasarkan prinsip syariah Islam. Baitul Maal wat Tamwil yang disingkat dengan BMT terdiri dari dua istilah, yaitu baitul maal dan baitul tamwil. Secara etimologis, istilah "baitul Maal" berarti "rumah uang”, sedangkan "Baitut Tamwil" mengandung pengertian "rumah pembiayaan. ${ }^{17}$ (Yunus, 2009 : 5).

Baitul maal lebih mengarah pada usaha-usaha pengumpulan dan penyaluran dana yang non profit. Seperti zakat, sedekah, infak. Sedangkan baitul tamwil merupakan suatu wadah yang lebih mengarah pada usaha-usaha pengumpulan dana dan penyaluran dana yang bersifat profit dengan memakai sistem profit and loss sharing, seperti pembiayaan murabahah, mudharabah dan lain sebagainya. Apabila digabung kedua istilah tersebut maka dapat dijelaskan bahwa BMT adalah balai usaha mandiri terpadu yang isinya berintikan bayt almaal wat tamwil dengan kegiatan mengembangkan usaha-usaha produktif dan infestasi dalam meningkatkan kualitas kegiatan ekonomi pengusaha kecil bawah dan kecil dengan antara lain mendorong kegiatan menabung dan menunjang pembiayaan kegiatan ekonominya. Selain itu, BMT juga bisa menerima titipan

\footnotetext{
${ }^{15}$ Veithzal Rivai, Manajemen Sumber..., h. 309.

${ }_{17}^{16}$ Alfian, http://www.Scribd.com.

17 Yunus, Jamal Lulail, Manajemen Bank Syariah Mikro, (Malang: UIN Malang Press, 2009), h. 5.
} 
zakat, sedekah, dan infak, serta menyalurkannya sesuai dengan yang telah ditentukan dalam syariat Islam. ${ }^{18}$

Dari segi istilah BMT adalah sekelompok orang yang menyatukan diri untuk saling membantu dan bekerja sama membangun sumber pelayanan keuangan guna mendorong dan mengembangkan usaha produktif dan meningkatkan taraf hidup para anggota dan keluarganya (mudal pelatihan pengelolaan BMT). ${ }^{19}$

Berdasarkan defenisi diatas dapat disimpulkan bahwa KJKS BMT mempunyai dua fungsi, yaitu fungsi non profit department sebagai landasan historis bahwa baitul maal pada masa Islam klasik adalah berfungsi sebagai dana umat dan penyeimbang perekonomian, sedangkan fungsi kedua yaitu fungsi profit department karena sebagai perpanjangan tangan dari bank Syariah. Kemampuan perbankan sangat terbatas untuk menjangkau sektor usaha mikro dan kecil sehingga dibutuhkan lembaga keuangan yang komersial seperti bank sehingga dapat menjangkau sektor tersebut, lembaga itu adalah KJKS BMT. Jadi yang menjadi ciri-ciri BMT dari pengertian di atas adalah :

1) Berorientasi bisnis, mancari laba bersama, meningkatkan pemanfaatan ekonomi paling banyak untuk anggota dan lingkungannya.

2) Bukan lembaga sosial tetapi dapat dimanfaatkan untuk mengefektifkan penggunaan zakat, infak, dan sedekah bagi kesejahteraan orang banyak.

3) Ditumbuhkan dari bawah berlandaskan peran ikut serta masyarakat disekitarnya.

4) Milik bersama masyarakat kecil bawah dan kecil dari lingkungan BMT itu sendiri, bukan milik orang atau orang dari luar masyarakat.

Sebagai lembaga perkonomian umat, baitul maal wat tamwil memiliki ciriciri sebagai berikut:

1) Bukan lembaga sosial, tetapi dapat dimanfaatkan untuk mengelola dana sosial seperti zakat, infaq,shadaqah, hibah dan wakaf.

2) Lembaga ekonomi umat yang dibangun dari bawah secara swadaya yang melibatkan peran serta masyarakat.

18 Djazuli, Lembaga-Lembaga Perekonomian Umat Sebuah Pengenalan, (Jakarta: PT Raja Grafindo Persada, 2002), h. 183. 124.

${ }_{19}$ Suhrawardi Lubis, Hukum ekonomi Islam, (Jakarta: Sinar Grafika, 2012), h. 
3) Lembaga ekonomi milik bersama.

4) Berorientasi bisnis. ${ }^{20}$

C. Pembahasan

1. Standar Kinerja KJKS BMT Sejahtera Belimbing dan Pendapatan dari Data Keunagna Mulai Pada Tahun 2010 - 2014

Tabel: 1.1

Standar Kinerja dan Pendapatan

\begin{tabular}{|l|l|l|}
\hline TAHUN & $\begin{array}{l}\text { STANDAR KINERJA } \\
\text { (TARGET) }\end{array}$ & $\begin{array}{l}\text { PENDAPATAN } \\
\text { (REALISASI) }\end{array}$ \\
\hline 2010 & Rp. 125.000.000 & Rp. 117.152.025 \\
\hline 2011 & Rp. 356.904.360 & Rp.643.902.000 \\
\hline 2012 & Rp.3 16.800.000 & Rp.300.589.420 \\
\hline 2013 & Rp.531.000.000 & Rp. 661.646.000 \\
\hline 2014 & Rp. 700.000.000 & Rp.550.000.000 \\
\hline
\end{tabular}

Sumber : Dokumen tahun (2010 -2014)

Pada tahun 2010 target KJKS BMT Sejahtera sebesar Rp.125.000.000 sedangkan pendapatannya sebesar Rp.117.152.025 ini berarti target KJKS BMT Sejahtera pada tahun 2010, tidak tercapai. Jika dilihat pada tahun 2011 target yang di tetapkan oleh KJKS BMT Sejahtera sebesar Rp. 356.904 .360 dan pendapatan KJKS BMT Sejahtera sebesar Rp. 643.902 .000 berarti pendapatan KJKS BMT Sejahtera pada tahun 2011, melebihi target yang telah direncanakan sebelumnya. Dilihat pula pada tahun 2012 target yang direncanakan oleh KJKS BMT Sejahtera sebesar Rp. 316.800.000 sementara pendapatan KJKS BMT Sejahtera sebesar Rp. 300.589.420 target yang ditetapkan oleh KJKS BMT pada tahun 2012 tidak tercapai. Sedangkan tahun 2013 target yang ditetapkan oleh KJKS BMT Sejahtera sebesar Rp. 117.995.000 pendapatan KJKS BMT tahun itu hanya sebesar Rp. 661.646 .000 berarti pada tahun 2013 melebihi target yang ditetapkan. Sementara pada tahun 2014 target yang ditetapkan oleh BMT Sejahtera sebesar Rp. 700.000.000 sedangkan pendapatan tahun 2014 sebesar Rp. 550.000.000 berarti target yang ditetapkan oleh BMT pada tahun 2014 tidak dapat tercapai. h. 64 .

${ }^{20}$ Ahmad Rodoni, dkk, Lembaga Keuagan Syariah, (Jakarta: Zikrul Hakim, 2008), 
Berdasarkan data yang penulis jabarkan di atas dapat disimpulkan bahwa kinerja KJKS BMT Sejahtera tidak stabil, dilihat dari pendapatan tahun ke ketahun turun naik. Wirawan menyebutkan standar kinerja adalah tolok ukur minimal kinerja yang harus dicapai karyawan secara individual atau kelompok pada semua indikator kinerjanya atau dapat diartikan Standar kinerja merupakan eksperesi mengenai ambang kinerja. Persyaratan, atau harapan yang harus dicapai untuk setiap elemen pada level kinerja tertentu. ${ }^{21}$

Adapun persyaratan standar kinerja KJKS BMT Sejahtera, sebagaimana yang dikatakan oleh manager KJKS BMT Sejahtera persyaratan bahwa :

"Persyaratan yang harus dilalui untuk setiap bagian dalam menentukan standar kinerja yaitu target harus tercapai, menuliskan berapa jumlah standar kinerja yang direncanakan yaitu Rp.2000.000 perhari setiap individu, kemudian standar kinerja sub tim Rp.6000.000 perhari langkah selanjutnya yang dilakukan manager mensosialisaikan kepada karyawan seperti KJKS BMT mengadakan rapat yang diadakan dikantor pusat KJKS BMT Sejahtera yang bertempat di Tabing J1. Adinegoro sebanyak dua kali tujuan KJKS BMT dalam mensosialisasikan standar kinerja atau target kepada karyawan agar karyawan tahu berapa target yang mau dicapai. $^{22}$

Dalam mensosialisasikan standar kinerja managerpun menanyakan kepada karyawan, apa ada diantara mereka yang tidak setuju dengan target yang direncanakan dan KJKS BMT melihat kemampuan kinerja karyawan dari laporan keuangan sebelumnya ${ }^{23}$ Hasil wawancara di atas juga dikuatkan dengan dokumentasi yang didapatkan pada laporan pendapatan dan target atau standar kinerja KJKS BMT Sejahetra bahwa tentang persyaratan yang harus dilalui untuk setiap bagian dalam menentukan standar kinerja yaitu target harus tercapai, menuliskan berapa jumlah standar kinerja yang direncanakan sebelumnya dan langkah selanjutnya yang dilakukan manager yaitu mensosialisaikan kepada karyawan seperti mengadakan rapat yang diadakan dikantor pusat sebanyak dua kali, agar karyawan tahu berapa target yang mau dicapai.

\footnotetext{
${ }^{21}$ Wirawan, Evaluasi Kinerja Sumber..., h. 65.

${ }^{22}$ Nadirman, Wawancara Pribadi: 18 Juni 2015.

${ }^{23}$ Nadirman, Wawancara Pribadi: 18 Juni 2015.
} 
Kemudian tentang cara KJKS BMT dalam menjalankan persyaratan standar kinerja adalah menurut Kepala Cabang KJKS BMT Sejahtera mengatakan bahwa:

"Agar tercapainya standar kinerja maka perlu dilakukan pengawasan dan evaluasi, ada dua bentuk pengawasan yang dibuat yaitu pengawasan langsung dan pengawasan tidak lansung. Bentuk pengawasan langsung saat karyawan bekerja diawasi langsung oleh kepala cabang KJKS BMT Sejahtera Belimbing dan pengawasan tidak langsung yaitu manager melihat dari laporan keuangan KJKS BMT yang dilaporkan bendahara kepada manager dalam bentuk laporan keuagan pertahun. Dari hasil laporan keuangan itu manager bisa menilai kinerja karyawannya selama satu tahun, apabila target tidak tercapi maka langkah selanjutnya yang dilakukan KJKS BMT mengevaluasi hasil kinerja yang belum tercapai. Kegiatan evaluasi dilakukan KJKS BMT 2 kali dalam satu bulan dan ada juga evaluasi yang dilakukan di akhir tahun. ${ }^{24}$

Selanjutnya cara manager membuat karyawan agar mampu menjalankan standar kinerja, sebagaimana yang dikatakan Nadirman sebagai manager KJKS BMT mengatakan:

“Agar para karyawan bisa menjalankan standar kinerja yaitu dengan memberikan dua macam pelatihan, adapun pelatihan yang berlangsung adalah manajemen risiko dan pelatihan kopetensi. Pelatiahan manajemen risiko yaitu pelatihan tentang masalah-masalah manajemen dalam mengelola perusahaan atau organisasi yang efektif didalam pelatihan itu manager dan kepala cabang diajarkan cara bagaimana mengelola KJKS BMT Sejahtera yang efektif. $^{25}$

Pelatihan kopetensi ini diadakan pelatihan khusus kepada seluruh karyawan KJKS BMT Sejatera seperti pelatihan pembiayaan, tabungan, marketing artinya sesuai dengan jabatan karyawan masing-masing yang dipercayakan kepada mereka. Sementara KJKS BMT Sejahtera mengadakan pelatihan tersebut di kantor pusat KJKS BMT Sejahtera yang berada di tabing dan didatangkan oleh KJKS BMT pemateri dari Jakarta, KJKS BMT melaksanakan pelatihan seperti itu di pertegahan tahun alasan KJKS BMT dalam melaksanakan pelatihan di pertengahan tahun dikarenakan karyawan tidak terlalu sibuk dengan tugasnya di kantor. $^{26}$

\footnotetext{
24 Juneldi Haris, Wawancara Pribadi: 20 Juni 2015.

${ }^{25}$ Nadirman, Wawancara Pribadi: 18 Juni 2015.

${ }^{26}$ Nadirman, Wawancara Pribadi: 20 Juni 2015.
} 
Berdasarkan hasil wawancara di atas dapat penulis pahami bahwa dalam meningkatkan kinerja karyawan, KJKS BMT Sejahtera melakukan pelatihan agar kinerja karyawan meningkat pendapatan dari tahun ketahun dan karyawan lebih mengerti masalah-masalah pekerjaannya seperti pembiayan, tabungan, marketing.

Kemudian tahapan yang dilakukan maneger KJKS BMT Sejahtera agar standar kinerja tercapai terlebih dahulu maneger mensosialisasikan kepada semua karyawan didalam mensosialisasikan manager membuat rencana tentang uraian kegiatan karyawan serta tanggung jawab karyawan dalam menjalankan tugas mereka masing-masing. Kemudian diterapkan terhadap tugas yang diuraikan tadi dibantu juga oleh manager dan kepala cabang dalam menerapkan tugas karyawan. ${ }^{27}$ Jika standar kinerja melebihi target yang ditentukan, sebagaimana yang dikatakan oleh bendahara KJKS BMT Sejahtera yaitu:

“Apabila terdapat target yang melebihi atau untung dalam menjalankan standar kinerja, KJKS BMT menggunakan untung tersebut sebagai modal untuk lebih berkembangnya keuagan KJKS BMT Sejahtera dan memberi bonus atau reward kepada karyawan bagi yang disiplin dan menjanjikan jabatan yang lebih tinggi untuk karyawan yang berprestasi dalam menjalankan kinerja. ${ }^{28}$

Berdasarkan hasil wawancara dan obervasi di atas dapat dipahami bahwa standar kinerja menetapkan tingkat kinerja pekerjaan yang diharapkan dari pelaksana pekerjaan dan kriteria pengukuran kesuksesan pekerjaan. Hal yang sama diungkapakan oleh Wirawan yaitu fungsi utama dari standar kinerja adalah sebagai tolok ukur (bechmark) untuk menentukan keberhasilan dan tidak, keberhasilan kinerja ternilai dalam melaksanakan pekerjaanya. Standar kinerja merupakan target, atau tujuan upaya kerja karyawan dalam kurun waktu tertentu, dalam melaksanakan pekerjaan karyawan harus mengarahkan semua tenaga, pikiran, keterampilan, pengetahuan dan waktu kerjanya untuk mencapai apa yang ditentukan standar kinerjanya.

Selanjutnya harapan KJKS BMT Sejahtera yaitu setelah menyelesaikan proses penulisan standar kinerja yang disepakati, Sekretaris KJKS BMT Sejahtera mengatakan bahwa karyawan harus bisa menyelesaikan pekerjaan dengan baik,

\footnotetext{
${ }^{27}$ Nadirman, Wawancara Pribadi: 20 Juni 2015.

${ }^{28}$ Piskar Handayani, Wawancara Pribadi: 20 Juni 2015.
} 
disiplin waktu dalam bekerja, dan mampu mencapi target yang ditetapkan sebelumnya, bisa melayani nasabah, memberikan kontribusi seperti mampu membuat KJKS BMT Sejahtera lebih maju dari BMT lain dan BMT bisa meraih peningkatan pendapatan dari tahun-tahun sebelumnya. ${ }^{29}$

Hal yang sama juga diungkapkan oleh maneger KJKS BMT Sejahtera sebagaimana yang di katakan Pak Nadirman harapannya sama dengan harapan KJKS BMT, manager pun berharap kepada karyawan yang sedang menjalankan standar kinerja bisa meningkatnya prestasi kerja karyawan seperti target yang ditetapkan oleh maneger tahun ketahun bisa tercapai dan mampu menjaga kedisiplinan saat bekerja dengan baik. ${ }^{30}$ Kemudian usaha yang dilakukan KJKS BMT Sejahtera agar harapan terhadap kelancaran standar kinerja bisa berjalan dengan baik yaitu KJKS BMT memberikan bimbingan, pelatihan, motivasi. Adapun bimbingan yang diberikan KJKS BMT seperti diarahkan oleh kepala cabang bagi karyawan yang kurang mengerti masalah pekerjaannya, apabila manager tidak sibuk dengan pekerjaannya manager pun mengunjungi karyawannya pada tiap-tiap kantor cabang dan memantaunya pada saat melaksanakan pekerjaan dengan cara manager memantau karyawan pada saat bekerja yaitu menanyakan langsung kepada kepala cabang bagaimana karyawan dalam melaksanakan tugasnya dikantor. Kemudian memberikan pelatihan yang bersifat mandiri hanya kepada karyawan KJKS BMT sejatera saja, didatangkan oleh KJKS BMT dari Jakarta sebagai pemateri untuk memberikan pelatihanpelatihan yang diperlukan dipertengahan tahun. Tujuan KJKS BMT memberikan pelatihan tersebut agar karyawan bisa bekerja lebih efektif dan diadakan dikontor KJKS BMT Sejahtera.

Selanjutnya KJKS BMT Sejahterah memberikan motivasi kepada karyawan seperti yang dikatakan oleh sekretaris KJKS BMT bahwa:

"Dalam memotivasi karyawan KJKS BMT menjanjikan jabatan yang lebih tinggi bagi karyawan ang bisa mencapai target atau memberikan kontribusi bagi KJKS BMT tersebut, memberikan bonus dengan begitu karyawan dapat termotivasi dalam mencapai target dan menjalakan aktivitas di KJKS BMT Sejahtera ${ }^{31}$ Ditambahkan oleh KJKS BMT

\footnotetext{
${ }^{29}$ Zulkifli, Wawancara Pribadi: 25 Juni 2015.

${ }^{30}$ Nadirman, Wawancara Pribadi: 20 Juni 2015.

${ }^{31}$ Zulkifli, Wawancara Pribadi: 25 Juni 2015.
} 
Sejahtera juga berikan motivasi kepada karyawan yaitu manager KJKS BMT memberikan berupa motivasi ekstinsik terhadap karyawan yang sedang menjalankan standar kinerja, motivasi ektsrinsi yaitu yang datang dari luar diri karyawan untuk mengembangkan KJKS BMT misalnya dorongan dari Dewan pengawas KJKS BMT dan manager dengan cara memberikan bonus atau reward kepada karyawan dengan begitu karyawan akan lebih giat dalam melaksanakan tugasnya dan lebih bersemangat mencapai target, tujuan KJKS BMT melakukan maotivasi seperti itu agar pendapatan KJKS BMT lebih banyak dibandingkan dengan pendapatan tahun sebelumnya. ${ }^{32}$

Bedasarkan hasil wawancara yang penulis lakukan bahwa dapat diketahui bahwa motivasi yang dilakukan KJKS BMT Sejahtera dengan menberikan bonus serta menjajikan jabatan yang lebih tinggi tiap anggota yang dapat memberikan kontribusi bagi KJKS BMT dan dapat mencapai target yang ditentukan. Hal yang sama juga diungkapkan oleh Winardi bahwa motivasi adalah suatu kekuatan potensial yang ada dalam diri seorang manusia, yang dapat dikembangkannya sendiri atau dikembangkan dengan sejumlah kekuatan luar yang pada intinya berkisar sekitar imbalan moneter dan imbalan nonmoneter, yang dapat mempengaruhi hasil kinerjanya secara positif atau secara negatif, hal mana tergantung pada situasi dan kondisi yang dihadapi orang yang bersangkutan.

Jika KJKS BMT mengalami kerugian atau tidak dapat mencapi target yang ditetapkan sebelumnya, manager mengatakan bahwa KJKS BMT melakukan evaluasi kepada karyawan dan mencari akar masalah dari permasalahan yang ada, dan manager menanyakan kepada karyawan apa ada diantara mereka yang kesulitan dalam menjalakan kinerja yang diberikan, apabila karyawan ada yang mengatakan kesulitan melajalankan kinerja yang diberikan oleh KJKS BMT, maka manager memberikan tugas sesuai dengan ke ahliannya masing-masing, memberikan pengarahan kepada karyawan yang merasa kesulitan dengan begitu harapan BMT dapat berkembang sesuai dengan rencana yang ditetapkan sebelumnya. $^{33}$

\footnotetext{
${ }^{32}$ Nadirman, Wawancara Pribadi: 20 Juni 2015.

${ }^{33}$ Nadirman, Wawancara Pribadi: 18 Juni 2015
} 


\section{Ukuran Kinerja KJKS BMT Sejahtera Kelurahan Belimbing Kecematan Kuranji}

Secara formal, poduk akhir dan hasil pengukuran kinerja diwujudkan dalam suatu laporan yang disebut laporan kinerja sebagai suatu alat laporan yang berisikan informasi penting tentang tercapainya atau tidaknya kinerja yang telah ditetapkan. ${ }^{34}$ Diungkapkan oleh Bendahara KJKS BMT tentang hasil kinerja BMT Sejahtera yang didapat selama priode 2010 -2014 bahwa:

"Hanya dua tahun baru KJKS BMT mencapai hasil kinerja yang baik yaitu pada tahun 2013 pendapatan KJKS BMT bertambah dari tahun sebelumnya sebanyak Rp. 661.646.00 dan tahun 2011 Rp.643.902.0000 pada tahun-tahun itulah hasil kinerja yang didapat oleh KJKS BMT sampai sekarang. KJKS BMT masih berusaha agar tahun berikutnya bisa mencapai target yang direncanakan" Ditambahkannya: "Hal-hal yang mempengaruhi tercapainya hasil kinerja di KJKS BMT Sejahtera manager, kepala cabang yang mampu memberikan kontribusi berupa keahlian dan tenaga serta karyawan yang mau bekerja keras dalam menjalakan kinerja, dibantu juga dorongan, insentif dan motivasi yang diberikan manager dan Dewan pengawas KJKS BMT Sejahtera terhadap karyawan."35

Berdasarkan hasil wawancara dan dokumentasi yang penulis dapatkan dari laporan pendapatan dan target atau standar kinerja bahwa dapat diketahui bahwa hanya pada tahun 2013 dan tahun 2011 berhasil menigkatkan kinerja KJKS BMT dari tahun sebelumnya. Selanjutnya dijelaskan oleh kepala cabang KJKS BMT Juneldi Haris bahwa:

"KJKS BMT Sejahtera juga membandingkan hasil yang direncanakan dengan hasil yang diperoleh, KJKS BMT melihat berapa jumlah yang direncanakan sebelumnya dan berapa hasil yang diperoleh dari situ KJKS BMT bisa melihat apa hasil kinerja mereka dapat berjalan atau tidak, dan KJKS BMT Sejahtera menjadikan juga pendapatan KJKS BMT tahun ketahun sebagai perbandingan bagi karyawan yang menjalankan kinerja dari situ manager bisa melihat kinerja yang ada di BMT Sejahtera sesuai rencana atau tidak. ${ }^{36}$

Berdasarkan hasil wawancara yang penulis lakukan dapat penulis pahami bahwa KJKS BMT membandingkan hasil yang diperoleh dengan hasil yang direncanakan agar karyawan KJKS BMT dapat mengetahui hasil kinerjanya

\footnotetext{
${ }^{34}$ Cecilia, http://www.duniaesai.com, 15 Oktober 2008.

${ }^{35}$ Piskar Handayani, Wawancara Pribadi: 01 Juli 2015.

36 Juneldi Haris, Wawancara Pribadi: 03 Juli 2015.
} 
tercapai atau tidak. Menururt Ahmad Ruky bahwa Ukuran kinerja adalah pada akhir kurun waktu (periode) yang ditetapkan. Tibalah saatnya untuk melakukan penilaian yaitu membandingkan antara hasil yang direncanakan dengan hasil yang di peroleh. Dengan kata lain sasaran -sasaran tersebut harus diteliti satu persatu mana yang dicapai sepenuhnya (100\%), mana yang diatas standar (target) dan mana yang dibawah target atau tidak tercapai sepenuhnya. ${ }^{37}$

Kemudian cara KJKS BMT dalam mencapai target yang ditetapkan sebelumnya, sebagaimana yang dikatakan manager KJKS BMT yaitu:

"Dalam mencapai target yang telah ditetapkan bahwa karyawan harus disiplin dalam masuk kantor, bisa menggunakan waktu sebaik mungkin dalam menyelesaikan tugas, melihat kondisi perekonomian masyarakat karna ekonomi masyarakat membantu pendapatan KJKS BMT dan dibantu melalui pelatihan, moativasi yang datangnya dari luar diri karyawan dan bantuan yang diberikan manager kepada karyawan berupa fikiran dan tenaga. $^{38}$

Selanjutnya dalam meningkatkan ukuran kinerja kepala cabang KJKS KJKS BMT melakukan langkah-langkah seperti mengadakan evaluasi kinerja karyawan dua kali dalam sebulan, KJKS BMT bekarja dengan lebih bersemangat, menggunakan waktu bekerja dengan sebaik-baiknya untuk menyelesaikan tugas yang diberikan KJKS BMT dan KJKS BMT melihat kondisi ekonomi masyarakat setelah KJKS BMT mengetahui masalah ekonomi masyarakat KJKS BMT menurunkan target dan menyusun strategi agar tidak kalah saing dengan BMT lain. $^{39}$

Adapun target yang direncanakan untuk mencapai kinerja yang diperoleh, menurut bendahara KJKS BMT hasil kinerja yang direncanakan KJKS BMT pada tahun.2010 Rp.125.000.000, pada tahun 2011 Rp. Rp.356.904.360, pada tahun 2012 Rp. 316.800.000, pada tahun 2013 Rp. .531.000.000, pada tahun 2014 Rp. 700.000.000. Itulah hasil yang direncanakan oleh KJKS BMT Sejahtera tetapi menurut penjelasan bendahara KJKS BMT Sejahtra target yang

\footnotetext{
${ }^{37}$ Ahmad Rodoni, dkk, Lembaga Keuagan Syariah..., h. 159.

${ }^{38}$ Nadirman, Wawancara Pribadi: 06 Juli 2015

39 Juneldi Haris, Wawancara Pribadi: 03 Juli 2015).
} 
direncanakan oleh KJKS BMT Sejahtera Belimbing bahwa yang tercapai di bawah $90 \%{ }^{40}$

Kemudian ditambahkan oleh manager bahwa KJKS BMT dalam menentukan perencanaan hasil kinerja yang akan dicapai oleh KJKS BMT Sejahtera Belimbing mengadakan RAT atau RAKER yaitu rapat kerja akhir tahun selama tiga hari biasanya KJKS BMT mengadakan RAKER diluar kantor seperti dihotel disitulah disusun rencana kinerja selama satu tahun yang akan di jalankan oleh karyawan.

Manager menjelaskan dalam menentukan hasil yang direncanakan untuk mencapai hasil kinerja yang diperoleh KJKS BMT melihat kemampuan karyawan dalam berkinerja, dilihat juga dari kedisipilinan mereka dalam menjalakan tugas yang ditetapkan sebelumnya dan kemampuan karyawan dalam menggaet nasabah $^{41}$ Selanjutnya strategi yang dilakukan KJKS BMT jika target yang ditetapkan tidak berjalan sesuai dengan rencana sebagaimana yang dikatakan kepala cabang KJKS BMT dengan mencontrol kinerja karyawan, menurunkan target dari yang sebelumnya, mengevaluasi kinerja, memberikan bimbingan kepada karyawan serta pelatihan ${ }^{42}$ Kemudian Manager mengadakan penilaian pada kinerja karyawan dengan melihat laporan harian karyawan dan laporan keuangan, dari situ manager mengetahui karyawan yang berkerja dengan serius, kemudian manger menilai kinerja karyawan dari laporan keuangan pertahun yang diminta langsung oleh manger, dari situ KJKS BMT bisa melihat bagaimana kondisi perkembangannya selama satu tahun. ${ }^{43}$

\section{Kesimpulan}

Hasil penelitian dapat disimpulkan bahwa kinerja yang ada di KJKS BMT Sejahtera Belimbing terdapat ketidakstabilan dari laporan pendapatan dan target yang direncanakan. Oleh sebab itu KJKS BMT memberikan pelatihan umum, khusus dan motivasi. Sementara pelatihan umum itu seperti manajemen risiko khusus untuk manager dan kepala cabang, pelatihan khusus seperti kopetensi kepada seluruh karyawan. KJKS BMT Sejahtera juga memberikan motivasi

\footnotetext{
${ }^{40}$ Piskar Handayani, Wawancara Pribadi: 08 Juli 2015.

${ }^{41}$ Nadirman, Wawancara Pribadi: 06 Juli 2015.

42 Haris, Wawancara Pribadi: 03 Juli 2015.

${ }^{43}$ Nadirman, Wawancara Pribadi: 06 Juli 2015.
} 
kepada karyawan dengan di sertai juga reward agar karyawan lebih semangat dalam menjalakan kinerja yang direncanakan sebelumnya

\section{Daftar Referensi}

Al, Siti, Fajar dan Tri Heru, Manajemen Sumberdaya Manusia, Yogyakarta:sekolah tinggi ilmu manajemen YKPN, 2010.

Bayu Prawira, Ringkasan Tesis: Pengaruh Motivasi Terhadap Kinerja LPP (Lembaga Pembina Posyandu) di Kecamatan...,http://www.tesisilmiah.co.oc diakses pada 20-10-2013.

Rika Muldan, Wawancara Pribadi: 03 Februari 2015

Malayu Hasibuan, Manajemen Sumber Daya Manusia, Jakarta PT Bumi Aksara, 2010.

Veithzal Rivai, Manajemen Sumber Daya Manusia, Jakarta PT Granfindo persada, 2006.

Wirawan, Evaluasi Kinerja Sumber Daya Manusia, Jakarta, 2009.

Husaini Usman, Manajemen, Jakarta: PT Bumi Aksara, 2010.

file:///C:/Users/user/Documents/standar-dan-prosedur-kinerja-pekerjaan.html (di akses 14 Mei 2015 pukul 09:00 wib).

Achmad, S. Ruky. Sistem Manajemen Kinerja, Jakarata: PT Gramedia Pustaka, 2002.

Sony Yuwono, dkk, Petunjuk Praktis Penyusunan Balance Scorecard Menuju Organisasi yang Berorientasi pada Strategi, Jakarta: Gramedia Pustaka Utama, 2003.

Cecilia, Srimindarti, Balanced Scorecard Sebagai Alternatif Untuk Mengukur Kinerja, 2006, http://www.duniaesai.com, 15 Oktober 2008

Http:// metronews/videoprogram/detail/2o13/02/23/163/9 /3850/ robert- s- kaplan/ face-with- desi - anwar.

Alfian, http://www.Scribd.com.

Yunus, Jamal Lulail, Manajemen Bank Syariah Mikro, Malang: UIN Malang Press, 2009.

Djazuli, Lembaga-Lembaga Perekonomian Umat Sebuah Pengenalan, Jakarta: PT Raja Grafindo Persada, 2002.

Suhrawardi Lubis, Hukum ekonomi Islam, Jakarta: Sinar Grafika, 2012.

Ahmad Rodoni, dkk, Lembaga Keuagan Syariah, Jakarta: Zikrul Hakim, 2008.

Nadirman, Wawancara Pribadi: 18 Juni 2015.

Juneldi Haris, Wawancara Pribadi: 20 Juni 2015.

Piskar Handayani, Wawancara Pribadi: 20 Juni 2015.

Zulkifli, Wawancara Pribadi: 25 Juni 2015.

Piskar Handayani, Wawancara Pribadi: 01 Juli 2015. 